\title{
RE-COVERING THE LIMITS OF RECOGNITION: THE POLITICS OF DIFFERENCE AND DECOLONISATION IN JOHN BORROWS' RECOVERING CANADA: THE RESURGENCE OF INDIGENOUS LAW
}

Published in Australian Feminist Law Journal, Vol. 27, 2007

For us, the ownership of the territory is a marriage of the Chief and the land. Each chief has an ancestor who encountered and acknowledged the life of the land. From such encounters come power. The land, the plants, the animals and the people all have spirit, they all must be shown respect. That is the basis of our law.

Chief Delgamuukw, also known as Ken Muldoe, Opening Statement in the trial of Delgamuukw v. British Columbia ${ }^{1}$

I am not a prisoner of history. I should not seek there for the meaning of my destiny.

I should constantly remind myself that the real leap consists in introducing invention into existence.

In the world through which I travel, I am endlessly creating myself. I am a part of Being to the degree that I go beyond it.

Fanon, Black Skin, White Masks, 229

Let's face it. We're undone by each other. And if we're not, we're missing something.

Judith Butler, Precarious Life: The Powers of Mourning and Violence, 23

A 'revolutionary message in a reactionary time'?² John Borrows' book Recovering

Canada: The Resurgence of Indigenous Law, offers us something else- an intricate set of movements that traverse the space between the limits of contemporary political, legal and social structures and their very foundations. Borrows critiques the

\footnotetext{
I would like to thank John Borrows, Stewart Motha, and the participants of the Law and Humanities Junior Scholars Workshop, held in June 2005, for their provocative engagements with the piece, and most particularly the very helpful commentary of Ayelet Shachar and Sarah Harding. The comments of two anonymous reviewers were invaluable. All errors and omissions are my own.

${ }^{1}$ Delgamuukw v. British Columbia (1991), 79 D.L.R. $\left(4^{\text {th }}\right) 185$ (B.C.S.C.), Transcript, May 12, 1987, lines 25-38

${ }^{2}$ John Borrows uses this phrase to describe the wide range of progressive proposals encapsulated in the Report of the Royal Commission for Aboriginal Peoples released in 1996. Recovering Canada: The Resurgence of Indigenous Law (Toronto: University of Toronto Press, 2002) 139
} 
origins of the settler colonial state and its law, contemporary Aboriginal rights jurisprudence, and government policies that have left Aboriginal communities dispossessed and marginalized. He presents a passionate and nuanced critique of the failure of the recent political and legal recognition of Aboriginal rights to significantly change the lives of Aboriginal communities. ${ }^{3}$ In the best spirit of critique, Borrows also presents his audience with his vision of a new political and legal order in Canada, one which would not only heed the call for increased Aboriginal representation in political, legal, and social institutions, but one that would incorporate Aboriginal law and legal knowledges into existing legal structures. The author attempts to re-map the boundaries of citizenship to include other ways of being, other forms of governance, other ways of conceptualizing our relationships to land, resources, and each other.

John Borrows' book pushes the boundaries of several different and overlapping bodies of work. One is the existing work on Aboriginal rights in Canada; another is post-colonial literature that addresses issues of (cultural) identity, difference and rights; and third, the more specific literature on the concept of recognition. Borrows' book doesn't remain confined to one of these 'fields' of scholarly inquiry, but pushes the boundaries between them through innovative arguments and analyses.

The body of work on Aboriginal rights in Canada is of course very diverse in perspective, analysis and prescription. Aboriginal rights and legal scholarship necessarily encapsulates a wide range of disciplinary and topical threads. Some people have taken on the task of recovering histories of Aboriginal communities, with a view to re-shaping the dominant historiography of colonial settlement and attendant myths about the state of Aboriginal societies, cultural practices, laws, languages and bodies of knowledge. Other scholars have addressed the legislative and judicial

\footnotetext{
${ }^{3}$ Borrows, 139
} 
dimensions of colonial settlement; ${ }^{4}$ the relationship between Aboriginal rights and the nation-state; ${ }^{5}$ and others, the extent of ongoing and developing Aboriginal legal rights in Canadian jurisprudence. ${ }^{6}$

John Borrows' book is unique in that it addresses the history of colonial settlement, recognizes the myriad injustices levelled at Aboriginal societies, and also seeks to utilize Aboriginal law as a means of showing how the contemporary legacies of colonial settlement could be ameliorated. ${ }^{7}$ He holds the Supreme Court of Canada accountable for maintaining the fiction of the colonial assertion of sovereignty, and outlines several proposals for how law and 'the political' could be re-conceptualized and radically re-shaped so that Canada could move beyond the strictures of its predicament of being a putatively post-colonial nation that still carries the hallmarks of injustice that are a direct or indirect result of colonialism. ${ }^{8}$

In theorizing how the nation state can move towards post-coloniality, Borrows interrogates the relationship between non-Aboriginal and Aboriginal communities; and by doing so, raises the question of the identity of the nation. Recovering Canada traverses the growing body of post-colonial theory, with a focus on cultural difference,

\footnotetext{
${ }^{4}$ See for example Paul Tennant, Aboriginal Peoples and Politics: The Indian Land Question in British Columbia, 1849-1989; Dara Culhane, The Pleasure of the Crown: Anthropology, Law and First Nations (Burnaby: Talonbooks, 1998);

${ }^{5}$ See for example, Sakej Henderson, "Empowering Treaty Federalism" (1995) 58 Saskatchewan Law Review 241; Patrick Macklem, Indigenous Difference and the Constitution of Canada (Toronto: University of Toronto Press, 2002)

${ }^{6}$ See Kent McNeil, Emerging Justice: Essays on Indigenous Rights in Canada and Australia (Saskatoon: Native Law Centre, 2001); A. Walkem and H.. Bruce eds., Box of Treasures of Empty Box? Twenty Years of Section 35 (Canada: Theytus Books, 2003); M.Asch ed. Aboriginal and Treaty Rights in Canada: Essays on Law, Equality, and Respect for Difference (Vancouver: University of British Columbia Press, 1997)

${ }^{7}$ Of course, John Borrows is not alone in theorizing from an anti-colonial and post-colonial perspective. His book is an innovative contribution to a growing body of anti-colonial writings by indigenous and nonindigenous scholars and activists in the Canadian context. See for example, A. Walkem and H. Bruce eds., Box of Treasures of Empty Box? Twenty Years of Section 35 (Canada: Theytus Books, 2003); M. Battiste ed. Reclaiming Indigenous Voice and Vision (Vancouver: UBC Press, 2000); and Harold Cardinal's seminal work, The Unjust Society: The Tragedy of Canada's Indians (Edmonton: Hurtig, 1969); M.E. Turpel'Aboriginal peoples and the Canadian Charter: interpretative monopolies, cultural differences" (1989-1990) 6 Canadian Human Rights Yearbook 3; M.E.Turpel and O. Mercredi In the rapids: navigating the future of First Nations (Toronto: Viking, 1993).

${ }^{8}$ Some of which include the unjust distribution of material resources and land (Royal Commission on Aboriginal Peoples, Volume. 5 Renewal: A Twenty Year Commitment, Chapter 2 Economic Disparities, Government Expenditures and the Cost of the Status Quo (Ottawa: Supply and Services, 1996)); lower life expectancy among the Aboriginal population than for the non-Aboriginal population (Royal Commission on Aboriginal Peoples, Volume 3, Gathering Strength, Chapter 3, "Health and Healing"); and a higher proportion of incarceration of Aboriginal individuals. ( $R$ v. Gladue [1999] 1 S.C.R. paragraph 50)
} 
identity and rights. Borrows builds on existing critiques of the way in which culture has been conceived of and commodified within a paradigm of multiculturalism ${ }^{9}$ by demonstrating how Aboriginal law can and ought to be used and incorporated within mainstream jurisprudence. As I explore in greater detail below, he illuminates how embracing Aboriginal difference can mean the creation of sui generis law, which would be the unique result of both Aboriginal and common law legal reasoning and precedent.

Borrows skilfully presents the reader with an introduction to an alternative epistemological and ontological paradigm in which to think about relations between individuals, communities, and the environment. He also persuasively contests a dominant historiography that relegates indigenous legal knowledges and modes of governance to an irretrievable past. Borrows presents a compelling 'un-covering' and interpretation of histories that refute common sense assumptions that Aboriginal sovereignty, including self-governance, modes of land use, and legal orders, were not recognized during the time of settlement or were extinguished. ${ }^{10}$ He elucidates the ways in which there was the simultaneous recognition and non-recognition of Aboriginal governance and laws. For instance, Borrows discusses early cases such as Connolly v. Woolrich ${ }^{11}$ and contemporary cases such as Casimel v. I.C.B.C., ${ }^{12}$ which demonstrate that Aboriginal laws have been recognized by the Canadian legal system over a long period of time.$^{13} \mathrm{He}$ also interprets historical treaties and contracts (such as the Two Row Wampum) in order to demonstrate what the intentions of Aboriginal and non-Aboriginal parties were at the time that treaties were

\footnotetext{
${ }^{9}$ See A.F. Gordon and C. Newfield eds. Mapping Multiculturalism (Minneapolis: University of Minnesota Press, 1996); Paul Gilroy, "Joined-up Politics and Postcolonial Melancholia" in Scott Lash and Mike Featherstone, Recognition \& Difference: Politics, Identity, Multiculture (London: SAGE, 2002), p.151; Paul Gilroy, After Empire: Melancholia or Convivial Culture? (London: Routledge, 2004); Elizabeth Povinelli, The Cunning of Recognition: indigenous alterities and the making of Australian multiculturalism (Durham: Duke University Press, 2002)

${ }^{10}$ Borrows, 11, 35

${ }^{11}$ (1867), 17 R.J.R.Q. 266 (Que.Q.B.). In this case, Cree customary law concerning marriage was recognized. Borrows, $5-6$.

${ }_{12}$ (1993) 106 DLR $\left(4^{T H}\right) 720$. In this case the British Solumbia Court of Appeal recognized Stellaquo adoption laws. Borrows, 6

${ }^{13}$ Borrows, 4-7
} 
reached, and how the vision of co-existence that this particular treaty reflects has not materialized. ${ }^{14}$ As Borrows point out, there has also been a parallel line of cases that have denied such recognition of Indigenous laws. Both historically and in contemporary caselaw, Aboriginal law and interests have been deemed to be a burden on Crown law, which is paramount. ${ }^{15}$ It is this line of reasoning that has been predominant and reflects a failure of recognition of Aboriginal law and interests, which, has in turn, resulted in the legal, political, social and economic repression and marginalisation of Aboriginal communities. ${ }^{16}$

In this review essay, I use Borrows' book as a focal point for a discussion of the concepts of recognition, identity and difference- themes which are undoubtedly important to the subject matter of his book and which also make his book relevant to a wide audience. I situate Borrows' work in current debates about the politics of recognition ${ }^{17}$, and the problems inherent in identity-based rights claims. Although these problems have been thoroughly dealt with in what is by now a rather large body of literature ${ }^{18}$, the problems with the identity/difference relation persist, as (some) marginalized communities continue to make claims for legal and political recognition as the means towards decolonization or liberation.

Borrows does not explicitly situate his work within the theories of recognition that derive their foundation from Hegel's theory of mutual recognition, as do Charles Taylor and Axel Honneth. However, it is my view that the substance of his arguments in Recovering Canada involve the question of legal recognition, the form which this

\footnotetext{
${ }^{14}$ Borrows, 150. Also see John Borrows, "Indian Agency: Forming First Nations Law in Canada" in Political and Legal Anthropology Review, Volume 24, No.2, 2001, p.9-24, at p.16

${ }^{15}$ Borrows, Recovering Canada, 7

16 Borrows, 8

17 The "politics of recognition" is a phrase that is most often used to refer to Charles Taylor's seminal essay, "The Politics of Recognition" in A. Gutmann ed. Multiculturalism: Examining the Politics of Recognition (Princeton: Princeton University Press, 1994). While I use the term to refer to his essay, I will distinguish his theory of recognition from a broader discussion of Hegel's dialectic of mutual recognition below.

${ }^{18}$ For critiques of the identity/difference formulation, and more particularly, identity politics and legal rights see William Connolly, Identity/Difference: Democratic Negotiations of Political Paradox (Ithaca: Cornell U Press, 1991); Wendy Brown, States of Injury: Power and Freedom in Late Modernity (Princeton: Princeton University Press, 1995); Didi Herman, Rights of Passage: Struggles for Lesbian and Gay Legal Equality (Toronto: University of Toronto, 1994); and Sherene Razack, Looking White People in the Eye: Gender, Race and Culture in Courtrooms and Classrooms (Toronto: University of Toronto Press, 1998)
} 
takes, and how the relations between subjects and communities of Aboriginal and non-Aboriginal subjects are formed through processes of recognition and reconciliation. Borrows' vision of a sui generis law and reconciliation are fundamentally about inter-subjective relations and mutual recognition, key aspects of theories of recognition that derive from Hegel, particularly through the thought of Charles Taylor. ${ }^{19}$ In this review essay, I illuminate how Borrows' conception of legal pluralism offers a significant challenge the limits of recognition as currently conceived in the Canadian context.

The invocation of cultural difference, as the basis for the recognition of Aboriginal rights by the state calls into question the substance of the 'identity' and 'difference' of Aboriginal subjects in relation to the dominant, non-Aboriginal majority. At stake in the recognition of the rights of the Aboriginal (legal) subject is the particular way in which this subject comes into being in relation to the non-Aboriginal population, and vice-versa. The phenomenon of recognition shapes the contours of both the marginalized subject who seeks recognition and those who "recognize".

The recognition of indigenous rights in Canada has failed, in many respects, to displace the colonial nature of legal and political relations. Recognition has been tied to a paradigm of identity and difference that is devoid of mutuality; the only legal recognition that has been realised is of the subject already proper to existing boundaries of colonial sovereignty. The Aboriginal subject claiming recognition has been circumscribed, in other words, by a restricted economy ${ }^{20}$ of recognition, in

\footnotetext{
${ }^{19}$ For instance, see Borrows' discussion of the recognition of Indigenous laws by the Canadian state at pages $4,5,9,11,12$; risks and effects of non-recognition at 90 ; discussion of pluralism and reconciliation at 8, 9, 12, 88-90; recognition of Aboriginal sovereignty at 97; and the dialogic transformations of communities involved in the recognition of indigenous laws at 148.

${ }^{20}$ I use the term "restricted economy of recognition" as a derivation from Derrida's critique of the Hegelian concept of the aufhebung in his essay "From Restricted to General Economy: A Hegelianism without Reserve" (Derrida 2003). In this piece, Derrida takes on Georges Bataille's critique and discussion of Hegel's thought as set out in L'expérience intérieure, "Hegel, la mort et le sacrifice" and other pieces (Bataille, 1990, 9-28). Derrida critiques the dialectic of recognition on the basis that potentially different shapes and forms of thought and Being are imprisoned within a "restricted economy" of meaning, history and life (Derrida, 2002a, 318,322). This is a restricted economy in which all meaning, and shapes and contours of Being, are caught within a logic of appropriation and reserve. Just as there is no space for difference to emerge within the dialectic of recognition (which presupposes a particular ideal of universal Humanity), there is no (easy) escape from the totalising dynamic of
} 
which the Court acknowledges only those rights claims that fit within already existing political, economic and legal relations founded upon a colonial sovereignty. The struggle for recognition can be understood as a means by which the sovereign self, in shoring up his own identity, refuses to recognise any desires, qualities and characteristics that do not mirror his own image and thereby subjugates the other who seeks recognition. I will explore this critique in detail below.

In the context of identity-based rights claims, recognition is thus understood to operate as a means by which the state, in reinscribing the legitimacy of its colonial foundations, refuses to recognise any qualities, characteristics, activities or customs that do not fit within the bounds of a colonial legal framework. As long as the recognition of the Aboriginal subject of rights is situated within this restricted economy, the relations of power that facilitated the marginalization of the Aboriginal subject is reinscribed- paradoxically, in the very claim for inclusion. ${ }^{21}$ In the colonial settler context, this conundrum appears to be practically inescapable. ${ }^{22}$

More specifically, the question that emerges from the critique of the restricted economy of recognition is whether the recognition of communities on the basis of their cultural, ethnic, or racial "distinctiveness" can avoid raising the spectres of essence and authenticity. By now a well worn argument, critics of an identity-based politics argue that asserting a right on the basis of a cultural, racial or ethnic identity presupposes the existence of a pure, reified essence that is constitutive of one's being. ${ }^{23}$ Ultimately, I argue that cultural difference operates as the modality through

appropriation and reserve. It is beyond the scope of my article to explore Derrida's critique in any more detail here.

${ }^{21}$ This point is made in depth by Wendy Brown, States of Injury: Power and Freedom in Late Modernity (Princeton: Princeton University Press, 1995) 99; and "Injury, Identity, Politics" in Mapping Multiculturalism A. Gordon and C. Newfield eds. (Minneapolis: University of Minnesota Press, 1996)149 at 151-155. Furthermore, as Wendy Brown argues, if the identity requires exclusion as its premise, then it can never be fully included within the polity or community from which it is excluded. 149 at 162

22 Thus, Fanon argued that 'recognition' in a dialectical sense was not possible in the colonial context, as the relationship between colonizer and colonized was strictly anti-dialectical. Fanon, Black Skin, White Masks trans. Charles Lam Markmann (New York: Grove Press, 1967) 220.

${ }^{23}$ A second issue, related the problem of cultural authenticity, is the paradox of representation any (or all) rights claims involve. While we can acknowledge that cultural identities are fluid, hybrid, and always changing, the moment that we make a rights claim based on these partial and contingent identities, it becomes necessary - at least momentarily- to represent this cultural identity in a complete, bounded 
which the totalising movement of the dialectic of recognition captures the "difference" that has always already been proper to the self- or the subject- which itself inscribes this difference. I will discuss how Borrows' conception of a sui generis legal order goes a great distance in breaking out of the pitfalls of cultural authenticity and the reification of the difference that has characterised the reception of Aboriginal rights claims by the courts. However, I also explore how this process of intersubjective recognition, which avoids the problems of reification and authenticity, could be realized butt the cost, paradoxically, of maintaining and preserving cultural difference.

While Borrows critiques the way in which Aboriginal rights have been conceived of and defined by the Courts both prior to 1982 and after the inauguration of section 35 of the Canadian Constitution ${ }^{24}$, he ultimately engages with notions of equality, democracy, legal (and cultural) pluralism, and the rule of law as the modes through which the transformation of existing circumstances can take place. Borrows uses the contemporary disavowal of racist and colonial dichotomies between civilized and non-civilized, backward and modern to argue that in order to create a political community that upholds the rule of law and democracy- in order to create what Canada in fact already purports to be- vastly different structures of political and legal organization are required. I argue that the turn to these foundational legal concepts thwarts what is otherwise a radical pluralist vision.

form. It becomes necessary to represent the cultural community as possessing an essential difference that makes it distinct- because it is that distinctiveness that forms the basis of the rights claim. If identity formation is actually always in flux, and moreover, takes place between two subjects or more, then basing claims for justice on an identity of cultural difference would appear, to the contrary, to deny the existence of the subject and (its) particularity. It is beyond the scope of this article to explore this problem in any detail; however, for a recent treatment of this problematic in the context of constitutional democracies see Emilios Christodoulidis, "Paradoxes of Sovereignty and Representation" [2002] Journal of South African Law 108; and also see Jacques Derrida, "Declarations of Independence" (1986) 15 New Political Science 7.

24 Section 35 of the Canadian Constitution Act, 1982, provides the following: 35 (1) The existing Aboriginal and treaty rights of the Aboriginal peoples of Canada are hereby recognized and affirmed; (2) In this Act, "Aboriginal peoples of Canada" includes the Indian, Inuit and Métis peoples of Canada; (3) For greater certainty, in subsection (1) "treaty rights" includes rights that now exist by way of land claims agreements or may be so acquired; (4) Notwithstanding any other provision of this Act, the Aboriginal and treaty rights referred to in subsection (1) are guaranteed equally to male and female persons. 


\section{PART I. RECOVERING CANADA: BORROWS' UNDERSTANDING OF THE PAST, CRITIQUE OF THE PRESENT AND VISION OF THE FUTURE}

A sustained critique of Borrows' book is difficult given its innovative structure and content. However, in an attempt to further the dialogue that this rich and bold offering invites, I will raise some questions about how recognition and difference are configured throughout the book. Before I get to that, however, I will highlight the most pertinent aspects of Borrow's analyses and arguments.

\section{A. Aboriginality and Aboriginal difference}

Borrows provides stunning critiques of Aboriginal rights jurisprudence as developed by the Supreme Court of Canada. In particular, he analyses the stated objectives of section 35(1), the conceptualisation of aboriginal rights, and how the content of such rights have been defined by the Supreme Court of Canada. Borrows points out that Aboriginal rights doctrine is informed by the objective of reconciliationthe reconciliation of the fact that prior to European settlement, "Aboriginal peoples were living in communities on the land" with "the sovereignty of the Crown". The Court acknowledges that Aboriginal rights exist because of the "simple fact that when Europeans arrived, Aboriginal peoples were already living on the land, in communities as they had done for centuries". ${ }^{25}$ Acknowledging this 'simple fact' of the pre-existence of Aboriginal communities on the land gives rise to a torrential flow of questions:

If Aboriginal peoples have prior rights to land and participatory governance, how did the Crown and court gain their right to adjudicate here? [Chief Justice Lamer] has to stem the flow. He has to regain his footing. He plants a flag. ' $[A]$ boriginal rights recognized and affirmed by s.35(1) must be directed towards the reconciliation of the pre-existence of [A]boriginal societies with the sovereignty of the Crown.' Chief Justice Lamer now has a purpose with which to capture both the Aboriginal and the right- 'the reconciliation of pre-existing claims to the territory that now

\footnotetext{
${ }^{25}$ This is a paraphrase of Lamer CJ in Van der Peet at paragraph 30 as cited in Borrows, 59.
} 
constitutes Canada, with the assertion of British sovereignty over that territory. ${ }^{26}$

Having stated the objects of reconciliation, Lamer CJ (for the majority) goes on to define the meaning of "Aboriginal". "Aboriginal" is defined by the Lamer CJ to denote that which was integral to the distinctive, pre-existing cultures of the Aboriginal communities prior to contact with European settlers. To establish an Aboriginal right, the claimant must prove that the practise, custom, or tradition was "integral to the distinctive culture" of the community prior to contact with Europeans. ${ }^{27}$ As Borrows puts it, "Aboriginal is retrospective." 28

Borrows critiques the temporal dimension of the court's definition of Aboriginal rights. By basing Aboriginal rights on the distinctive cultures of Aboriginal communities as they existed prior to contact, the Supreme Court of Canada repeatedly "relegates Aboriginal peoples to the backwaters of social development, deprives them of protection for practices that grew through intercultural exchange, and minimizes the impact of Aboriginal rights on non-Aboriginal people."29

Borrows argues that the concept and definition of Aboriginal rights should be based on the historical and continued recognition of the "laws and customs of Indigenous peoples" ${ }^{30}$ Practises that were formed as a result of contact with European settler communities, practices that developed in order to ensure the survival of Aboriginal communities should also receive constitutional protection. ${ }^{31}$ Borrows advocates for a conception of Aboriginal rights that protect practices that are necessary for the "physical and cultural survival" of the community. ${ }^{32}$ The purpose of protecting Aboriginal rights should "not necessarily be to preserve distinctive

\footnotetext{
${ }^{26}$ Borrows, 59

27 R. v. Van der Peet, [1996]2 S.C.R.507 at 549, per Lamer CJC, see Borrows at 60.

${ }^{28}$ Borrows, 60

${ }^{29}$ Borrows, 61

${ }^{30}$ Borrows, 70

${ }^{31}$ This approach would more substantively reflect the two dissenting judgments in Van der Peet, both of which argued that positing the time prior to contact as the temporal referent point for defining Aboriginal rights has the effect of 'freezing' Aboriginal rights in a pre-contact era, denying them protection of the 'right to adapt' to changes in society. Borrows, 61-64

${ }^{32}$ Borrows, 63
} 
elements of pre-contact culture", but to ensure the survival of those communities today.

As Borrows points out, the Court, in Van der Peet, first found it necessary to define the term 'Aboriginal' for the purposes of adjudicating Aboriginal rights claims. Aboriginal difference from what is non-Aboriginal lies at the heart of Aboriginal rights doctrine. This basis of the right itself, entrenches the concept of 'essence' at the heart of Aboriginal rights doctrine- it presupposes as its constitutive criteria something distinctly - or essentially- Aboriginal about the right being asserted. While I wholeheartedly agree with Borrows' critique of the way in which the majority of the Supreme Court of Canada has defined Aboriginal rights, I will pose some additional questions below about the basis of Aboriginal rights, and the pitfalls of defining the rights of Aboriginal peoples through the notion of Aboriginality in the Canadian context.

\section{B. Indigenous legal knowledges and radical legal pluralism; or, sui generis law}

In the face of the misrecognition of Aboriginal legal knowledge and the consequent injustices it has wrought, Borrows makes an argument for the recognition of Aboriginal law and legal knowledges on the basis of "tests aimed at reconciliation which suggest First Nations laws should receive substantial protection from conflicting non-Aboriginal laws in [certain] circumstances". ${ }^{33}$ Reconciliation becomes the means through which a meaningful recognition of Aboriginal law ought to take place. Much of the book is a blueprint for the epistemological, ideological and correlative legal shifts that are necessary in order to effect such a reconciliation. ${ }^{34}$

Borrows introduces his readers to Indigenous conceptions of law and illustrates how different legal orders can inform one another in such a way as to create a genuinely unique and plural legal order. The notion of a sui generis legal order that

\footnotetext{
33 Borrows, 9

${ }^{34}$ Reconciliation, as a political and legal means of dealing with the legacies of colonialism, has been critiqued as yet another form of political domination. See Bhandar (2007); Motha (2007).
} 
would result from the 'co-mingling' of various Aboriginal and non-Aboriginal legal orders would create something entirely unique, in which the maintenance of difference - a difference that distinguishes itself from what is the same in some essential way- would not, ultimately, be possible or even desirable. I argue that the notion of a sui generis legal and political order provides a movement towards a more radically anti-essentialist basis for political community than does a politics of difference. I also want to suggest that the politics of difference through which the recognition of difference currently takes place in the Canadian judicial context is not compatible with the notion of sui generis law for which Borrows argues. The politics of difference, and the difference which it preserves, relies on an idea or representation of a community's essence or (essential) being.

The first shift that Borrows identifies as required for reconciliation is in the realm of language. There is a need for courts to "find more appropriate terminology to describe Aboriginal rights" and "[u]ltimately this requires recognizing a category of Canadian law to receive First Nations law."35 This terminology can already be found to exist- in the term sui generis. Characterizing Aboriginal rights as sui generis reflects the acknowledgement that these rights derive their meaning and very existence from Aboriginal legal and political sources along with the common law. Borrows argues that the sui generis doctrine encapsulates the balance and interplay between similarity and difference that exists (or ought to exist) between Aboriginal and non-Aboriginal communities.

The sui generis doctrine expresses the confidence that there are sufficient similarities between the groups to enable them to live with their differences. Under this doctrine, points of agreement can be highlighted and issues of difference can be preserved to facilitate more productive and peaceful relations. The sui generis doctrine reformulates similarity and difference and thereby captures the complex, overlapping, and exclusive identities and relationships of the parties. ${ }^{36}$ (emphasis added)

\footnotetext{
${ }^{35}$ Borrows, 9

${ }^{36}$ Borrows, 10
} 
There is a potential contradiction between arguing for the development of a sui generis form of law while at the same time arguing for the preservation of difference. Borrows' preferred vision of legal pluralism is not one that entails a simple expansion of existing legal and political institutions to include Aboriginal perspectives (although this is definitely one aspect of his argument), but rather, a co-mingling of legal knowledges and orders that would in effect create something entirely unique, or sui generis. Borrows' concept of a sui generis legal order challenges an economy of similarities (or 'sameness') and 'difference' which rely upon reified or essentialist understandings of cultural difference in order to envision the creation of a unique order of law and legal knowledges.

\section{Re-mapping the rule of law}

In Chapter 4, Borrows renders a stunning and detailed analysis of Delgamuukw v. British Columbia. ${ }^{37}$ Among the many arguments that he makes, he exposes the "myth of sovereignty" in his analysis of the judgment of the Supreme Court of Canada. ${ }^{38}$ The Court refuses to question the legitimacy of Crown sovereignty, and its basis remains nothing other than self-assertion. ${ }^{39}$ This continual refusal to question the legitimacy of colonial sovereignty enables the characterization of Aboriginal title as a mere burden on underlying Crown title.

This critique of the colonial assertion of sovereignty and its continual reiteration in Aboriginal rights jurisprudence is set within a larger critique of a liberal form of rights. Borrows- with the assistance of the Trickster who readily performs several deconstructive moves throughout the text- explores how the notion of 'equality' can be used to promote the rights of any individual or group- in spite of the relations of power that structure and situate individuals differently in relation to one

\footnotetext{
${ }^{37}$ (1991), 79 D.L.R. $\left(4^{\text {th }}\right) 185$ B.C.S.C.; (1993), 104 D.L.R. $\left(4^{\text {th }}\right) 470$; [1997] 3 S.C.R. 1010

${ }^{38}$ For interesting accounts and analyses of the concept of sovereignty as delineated in Mabo v. The State of Queensland (No.2) (1992) 175 C.L.R. 1, see S. Motha and C. Perrin (eds). 'Special Issue: Deposing Sovereignty After Mabo' (2002) 13(3) Law and Critique

${ }^{39}$ Borrows, 109
} 
another. The first exemplar of the 'myth' of 'equality' was the proposed White Paper of the Liberal government in 1969, which contained policies that were aimed at the assimilation of Aboriginal peoples as the means to achieving equality among all. Raven "sees how the promise of equality can become a pretext for eliminating different ways of evaluating life." ${ }^{40}$

Leaping to the present day, Raven (in the guise of a well known member of the media) provocatively makes a speech during a time of debate over the Nisga'a Final Agreement in which he speaks of "race based entitlements" and segregation. By invoking popular arguments about the perils of "special group rights" that were used by opponents of the Treaty, Raven is actually referring to the race based entitlements historically enjoyed initially by white European settlers, and then later, by other non-Aboriginal immigrants. The Trickster "wonders who [the audience] will see in his words, and to whom they will attribute wisdom and foolishness." ${ }^{41}$

Borrows points to the malleability of the concept of 'equality' within a liberal legal paradigm. Divorced from history and context, from relations of power that create systemic privilege, the ideal of 'equality' (along with a host of other human rights) is capable of being utilized by any group who perceives 'discrimination'- which in the case of non-Aboriginal peoples' opposition to the Nisga'a Final Agreement is more appropriately characterized as a potential loss of privilege that was created through the colonial subjugation of other peoples. ${ }^{42}$

\footnotetext{
${ }^{40}$ Borrows, 103

41 Borrows, 107

42 The plaintiffs in $R$. v. Kapp et al [2003] 4 CNLR 238 argued that their section 15 right to equality under the Charter had been violated by the Aboriginal Communal Fishing Licences Regulations, SOR/93-332 and the Aboriginal Fishing Strategy on the basis of race. The defendants accused were a group of non-Aboriginal fishermen. Interestingly, the provincial court judge found that the pilot sales fishery "draws a distinction and defines two groups on the basis of whether or not individuals have a bloodline connection to the Musqueam, Burrard, or Tsawwassen Bands", that this is "analogous to a racial distinction" and as a result violates the section 15 rights of the accused. He found that "this has the effect of promoting the view that these individuals are... less worthy of recognition, and less valuable as members of Canadian society." [para 203] Ultimately, finding that the regulations and fishery scheme are ineffectual, the judge found that they could not be "saved" or justified by section 1 of the Charter. This judgment was overturned on appeal, where Chief Justice Brenner of the B.C. Supreme Court held that the fishing regulations do not violate the section 15 equality rights of the defendants. $R$ v. Kapp et al [2004] 3 CNLR 269. The British Columbia Court of Appeal dismissed the appeal, [2006] 3 CNLR 282. An application for leave to appeal to the Supreme Court of Canada was filed on 6 September 2006 (SCC Bulletin, 2006, p.1181).
} 
Borrows critiques the unilateral declaration of Crown sovereignty that became the basis for the legitimisation of the extinguishment or infringement of Aboriginal rights prior to $1982 .{ }^{43}$ He points out the myriad flaws with Aboriginal rights doctrine that severely limit the constitutional protection of Aboriginal rights in s.35 of the Constitution, a recognition of rights that could have given way to a just reconciling of Aboriginal and non-Aboriginal sovereignties. ${ }^{44}$ Despite his critiques however, Borrows wants to base his claim for justice on traditional legal principles, in particular, the rule of law, along with federalism, democracy and the respect for minorities. Borrows rightfully critiques the refusal of the Court to question the legitimacy of the assertion of Crown sovereignty, the "frozen rights" approach to Aboriginal rights doctrine, the denial of Aboriginal perspectives of their rights and rights claims, and the continued marginalisation of the fact that Aboriginal peoples did not consent to the extinguishment of their rights and entitlements, in light of the contemporary disavowal of the colonial ideologies that underlay the settlement of Canada. However, I argue that contemporary understandings of 'humanity' as now including those peoples who were previously seen by Europeans as backwards and uncivilized, and therefore appropriate beings for colonial subjugation, and the law that facilitated this colonization, cannot be neatly divorced from one another. That is, the contemporary disavowal of ideologies of the past that underlay colonization cannot be neatly mapped onto foundational legal tenets such as rule of law. Rather, it is my view that such concepts also have a history - replete with blood and violence-

Even the perceived loss of privilege with the recognition of an Aboriginal treaty right to fish has sparked violence on the part of non-Aboriginal fishermen. Throughout the fall of 1999, Aboriginal fishermen on the east coast faced physical violence and harassment at the hands of non-Aboriginal fisherman after the Supreme Court of Canada reaffirmed the treaty right of the Mi'kmaq people to trade (fish) for necessaries. (See R. v. Marshall [1999] 3 S.C.R. 456) The storm of protest on the part of nonAboriginal fishermen and the motion for a re-hearing and a stay by the West Nova Fishermen's Coalition resulted in a further judgment, in which the Court clarified its initial judgment and reassured the petitioners that they had not affirmed a treaty right that was not subject to State regulation. (R. $v$. Marshall [No.2] [1999] 3 S.C.R. 533). The Court explained to the petitioners that the issue of whether the federal fishery regulations under which Donald Marshall had been charged were a justifiable limitation on the Mi'kmaq treaty right was not before the Court as the Crown had not made any such argument. Having found an Aboriginal treaty right to trade fish for necessaries, Donald Marshall was entitled to be acquitted of the charges of fishing out of season and other, related charges.

${ }^{43}$ Borrows, 108

44 Borrows, 97 
that cannot simply be emptied out and re-inscribed with new meaning in a clean, post-colonial sweep towards justice.

\section{PART II. RE-COVERING THE LIMITS: CALLING INTO QUESTION A POLITICS OF DIFFERENCE}

I have identified three different questions about the type of pluralism envisioned by Borrows and the limits of current form of recognition in the Canadian context. The first two issues relate to problems inherent in the politics of difference that underlies recognition, which in my view, Borrows successfully transcends. The third question is a critique of Borrows' reliance on fundamental legal tenets as the appropriate means through which to realise his radical legal pluralism.

The first question is about the potential for recognizing difference within a paradigm of recognition. What is the nature of the difference that is recognized? Is there space within a theory of mutual recognition for the recognition of a difference that encompasses ways of being, and relations between beings that derive from 'other' epistemological and ontological grounds? I argue that currently, the difference that is recognized within Aboriginal rights caselaw is only that which is proper to the self (or subject) who is already in existence. This is in large part due to the fact that (perhaps with the influence of the ideology of official multiculturalism in Canada), the difference that is recognized (and preserved) through Aboriginal rights claims is limited to the recognition of a cultural identity of "Aboriginality". The cultural difference that is recognized is defined as that which is proper to the existing political, economic and legal structures of the Canadian state. Defining Aboriginal difference in terms of cultural difference prevents a rupture of existing relations of power, rooted in the history of colonial settlement, which enables one entity to bestow recognition upon the party seeking legal rights from the state. In order for a meaningful shift towards a post-colonial political community, 'difference' would have to be defined in a way that accounts for the material, ontological and epistemological aspects of subject formation and rights claims. 
I argue that the legal changes and transformation Borrows proposes, the result of which can be characterized as sui generis law, rupture the boundaries of a restricted economy of recognition. The concept of sui generis law requires a substantive transformation of the colonial foundations of the legal system and the political-philosophical concepts that underlie governance and the economy. Given that the only difference that is cognisable within a paradigm of recognition is that which is proper to what already exists, I argue that the radical changes that would result from such a 'co-mingling of legal orders' could not be realised within the bounds of the recognition of cultural difference as it currently operates in the Canadian context.

The second question takes a slightly different point of departure. While a theory of recognition allows for the transformation of the subject or in this case, the nation, through the process of the mutual recognition of different communities, it also facilitates the preservation of 'difference'. If we accept Borrows' proposition that a melding of different legal orders is possible, in such a way as to create something new and unique but at the same time to preserve the integrity of these different strands of legal orders, is the preservation of cultural difference, with its problems of essence and authenticity possible or even desirable?

The final question I raise is about the basis upon which Borrows argues for a new legal and political order. He argues for the application of foundational concepts such as the rule of law, federalism, democracy and the respect for minorities in the move towards creating a just foundation for the Canadian state. My question concerns the rule of law, and the concept of sovereignty to which it is bound. Can the very radical notions of decolonisation (expressed in the first four chapters) be realized through the use of concepts such as the rule of law? How can concepts such as the 'rule of law' and 'sovereignty' which lay at the very foundation of colonial rule and settlement be redeployed in order to create a decolonised legal and political community? 
A. The essence of (cultural) difference and Hegel's dialectic of recognition

Within the paradigm of 'difference', difference has been defined as "cultural" difference. Charles Taylor's seminal essay on the topic, "The Politics of Recognition" emphasizes the centrality of the recognition of identity- as cultural and linguistic distinctiveness ${ }^{45}$ - to freedom from oppression and social harms. ${ }^{46}$ It is the mis- or non-recognition of people's identities that have contributed to a self-image of inferiority and other ills. ${ }^{47}$ The mutual recognition of identities by equals is the means to allowing individuals and cultural (linguistic) communities to attain full self-hood, equality and dignity. ${ }^{48}$

Taylor takes the dialectic of mutual recognition from Hegel, and transposes it into contemporary political and social struggles in the Canadian context, most notably, the struggle of the Quebecois for self-determination. Taylor defines identity as a term that "designates something like a person's understanding of who they are, of their fundamental defining characteristics as a human being" ${ }^{49}$ and also "who we are, 'where we're coming from'”. ${ }^{50}$ The universal quality that grounds the politics of difference (i.e. that quality or thing that provides sufficient similarity for all human beings to co-exist) is "the potential for forming and defining one's own identity, as an individual, and also as a culture." ${ }^{51}$ There is an important movement (or slippage) here from the individual to the cultural 'community' or collective. The leap from the desire for recognition of the modern individualist self to that of the social collectivity presents some difficulties. Taylor deals with this by way of reference to Herder,

\footnotetext{
${ }^{45}$ Charles Taylor, "The Politics of Recognition" in Amy Gutmann ed. Multiculturalism: Examining the Politics of Recognition (Princeton: Princeton University Press, 1994) at 25.

${ }^{46}$ Taylor, 25

47 Taylor, 65

${ }^{48}$ For other analyses of the politics of recognition, as derived from Hegel, see Axel Honneth and Nancy Fraser Recognition or Redistribution? A Political-Philosophical Exchange (New York: Verso Press, 2003); Robert R. Williams Hegel's Ethics of Recognition (Berkeley: University of California Press, 1997); John O'Neill ed. Hegel's Dialectic of Desire and Recognition: texts and commentary (Albany: State University of New York Press, 1996) Introduction p.1-25

49 Taylor, "Politics of Recognition", 25

50 Taylor, 33

51 Taylor, 42, emphasis added
} 
another major influence on his theory of multiculturalism: "I should note here that Herder applied his conception of originality at two levels, not only to the individual person among other persons, but also the culture-bearing people among other peoples. Just like individuals, a Volk should be true to itself, that is, its own culture..52 Mutual recognition between individual subjects occurs on the basis that the universal similarity between subjects is nothing else but the desire for recognition by another. Putting this desire into action, or petitioning or addressing the other for recognition- even before the recognition is realized- is a transformative process for the subject. ${ }^{53}$ While the term "culture" can signify a wide range of practices, knowledges, and ways of being, when placed in the paradigm of recognition, the fluidity and constantly changing nature of cultural practices becomes difficult, if not impossible to maintain when the phenomenon of recognition is transposed into a liberal democratic rights regime. The address or petition for recognition, when made by a cultural community, is on the basis of a difference that has to already be in existence if it is to be recognized. This means that in the act of a community representing itself as having a particular cultural identity, the fluidity, contingency and movement that is actually characteristic of practises and 'traditions' in cultural communities is captured. As Butler points out, this is inevitable in the context of asserting rights and claiming legal protection on the basis of membership in a group or class. ${ }^{54}$ She also notes that wrenching this 'captured' identity away from an understanding of who we are in a more general or broad sense is very difficult. ${ }^{55}$ Taylor, on the other hand, doesn't seem to distinguish between the relative "artificiality" of identity as it is represented within a liberal-legal paradigm, and what we really are about, which is a set of fluid, changing, fragmented and non-unitary

\footnotetext{
${ }^{52}$ Taylor, 31. For a fuller discussion of this issue, see K.A. Appiah "Identity, Authenticity, Survival: Multicultural Societies and Social Reproduction" in Amy Gutmann ed. Multiculturalism: Examining the Politics of Recognition (Princeton: Princeton University Press,1994) 149 at 153. For a critique of this aspect of Taylor's work see Andrew Schaap, "Reconciliation Through Struggle for Recognition?" in Social and Legal Studies 13 (4) (2004).

53 Judith Butler, Precarious Life: The Powers of Mourning and Violence (London: Verso, 2004), 46

54 Butler, 24

55 Butler, 25
} 
subjectivities. The failure of Taylor and the realities of a liberal rights paradigm conflate to inhibit the potential for transformation that exists in the process of recognition. The problems of reified cultural identities, which are premised on exclusionary essences rear their heads once again.

As a result, while the freedom to live and exist in a way that mirrors your selfunderstanding and expression of "who you are and where you are coming from" is, at face value, a desirable objective, it falls far short of the kind of radical transformation in relations between individual beings and communities- and indeed- the formation of political community itself- that is necessary for a move towards decolonisation. The recognition of different cultural identities leaves existing political and economic structures intact, and does not push the boundaries of existing social relations past the point of "tolerance" of cultural differences.

Borrows has pointed out the problems with relying on colonialist conceptions of Aboriginal culture as being "traditional" and static. He argues against this approach, and for the recognition of Aboriginal rights on the basis of Indigenous laws and customs. This raises the question of whether the concept of 'difference', within a paradigm of recognition, is capable of encompassing normative principles, values, and alternate epistemological foundations that ground Indigenous laws in different ways from Anglo-American legal principles. I argue that the recognition of difference is limited not only because of the content of this "difference"- i.e. cultural difference that has to be represented in a bounded way for the purposes of rights claims- but at a more fundamental level, 'difference' is recognized only when it is properly different to that which is the 'same'.

The argument that the politics of difference only allows for a difference that is proper to what already exists raises the more fundamental question about the nature of difference within the Hegelian dialectic of recognition. This question is complex and even a tentative conclusion cannot be drawn without exploring Hegel's theory of mutual recognition. In the context of Hegel's dialectic of recognition, the formation of 
the subject takes place through the mutual recognition of each other's Being. ${ }^{56}$ The master-slave dialectic is perhaps the most well known dimension of the dialectic of mutual recognition and I start my discussion with this scene in mind.

At the initial stage of the master-slave dialectic, and this stage of the development of self-consciousness, man seeks recognition from other men but has yet to see- and has failed to see- how he relates to (or is) the universal. In this failure, he has failed to see other men as beings equal to himself, but only sees the reflection of his own self in these men. ${ }^{57}$ The main principle man grasps is his superiority to others, and thus feels compelled to overcome this other in order to prove his superiority. Unlike at later stages, at this early stage man fails to recognize how recognition is "something that in principle should be extended to all." ${ }^{58}$ Recognition is not a mutual endeavour at this stage, but a kind of recognition that can only come to be in a situation of domination or war or even, and ultimately, the annihilation of the other.

However, annihilation defeats the purpose of the struggle for recognition. If I die, recognition is a moot issue. If the other dies, there is no other to give me the recognition I require. What is necessary is a "standing" ${ }^{59}$ or a "living" ${ }^{\text {" }} 0$ death in which my other is overcome but remains in existence. The realization of the need for the "living death" of my other is the initial resolution of the paradox between the desire to annihilate or overcome the other in seeking recognition from him, which would leave me without recognition. The need for recognition becomes mutual. ${ }^{61}$

\footnotetext{
${ }^{56}$ The master slave dialectic is perhaps the most well known dimension of the dialectic of mutual recognition, and while I risk oversimplification, I will draw a few basic conclusions from this 'scene' of the dialectic of recognition that are pertinent to my inquiry.

${ }^{57}$ Hegel's Phenomenology of Spirit Selections trans. and annotated by Howard P. Kainz, §179, p.50

58 Taylor, Hegel (Cambridge: Cambridge University Press, 1975) 153

59 Taylor, 153

${ }^{60}$ Butler, Subjects of Desire: Hegelian Reflections in Twentieth-Century France (New York: Columbia University Press, 1999) 52

${ }^{61}$ Important in the context of the master-slave dialectic is that one side gives in just before it comes to death, recognizing it's attachment to life, and becomes enslaved by the other. In order to avoid death, the slave submits to the master's will. While the master becomes complacent in his position of power over his slaves, who recognize his self and superiority, the slaves eventually recognize, through their labour and work in the world, their power to transform the world, the external reality. In this realization of their power over their environment, the seeds of their liberation lie. Taylor describes this as a
} 
What is required by the self-consciousness struggling for recognition is a relationship with the (or its) other which will reflect the reality of self-consciousness' being as an "emanation of universal Geist." ${ }^{\text {"2 }}$ The realization of each subject's relationship to the universal, and the desire to create and to be sustained by an external reality that reflects this relationship, requires recognition by an other human being who "will annul its own foreignness, [but] in which the subject can nevertheless find himself." ${ }^{\prime 3}$ This recognition is found not as or in an(other) human being existing merely as a subject in existence-for-itself, but as - and in - a human being who recognizes the humanity of the self-consciousness seeking recognition.

Hegel's theory of the coming into being of the subject and intersubjective relations are two aspects of the same process; self-consciousness cannot come into being fully without the recognition of an other self-consciousness, and without the other who is simultaneously seeking the recognition of the other self-consciousness as well. In the context of this double signification, where self-consciousness comes into being through a kind of mutual recognition, it "comes out of itself" and appears to posit its other. Self-consciousness posits its other insofar as it believes, mistakenly, that the other (self-consciousness) is not independent (when in fact it is). Selfconsciousness, in the initial moment, overcomes its other. The self splits; "the middle breaks forth into extremes;" one of which is the merely recognized, and the other is the merely recognizing.$^{64}$ Each extreme exists in opposition to the other; and the opposition is overcome as they each transform into their opposites. But what of the middle term, self-consciousness?

Although, as consciousness, it does indeed come out of itself, yet, though out of itself, it is at the same time kept back within itself, is for itself, and the self outside it, is for it. It is aware that it at once is, and is not, another consciousness, and equally that this other is for itself only when it supersedes itself as being for itself, and is for itself only in the being-for-

\footnotetext{
foreshadowing of historical materialism- "conceptual thinking arises out of the learned ability to transform things." Taylor, 157

${ }^{62}$ Taylor, 149

${ }^{63}$ Taylor, 152

${ }^{64}$ Hegel, Phenomenology of Spirit, trans. A.V. Miller (Oxford: Oxford University Press, 1977) §185 p.53
} 
self of the other. Each is for the other the middle term, through which each mediates itself with itself and unites with itself; and each is for itself, and for the other, an immediate being on its own account, which at the same time is such only through this mediation. They recognize themselves as mutually recognizing one another. ${ }^{65}$ (emphasis added)

We can see from this passage that each self-consciousness relies upon another independently existing self-consciousness to similarly transform itself. Self-

consciousness seems to be both another consciousness and independent of this other consciousness. Gillian Rose offers an interpretation of the presentation of otherness in Hegel's dialectic in the following terms:

[T]he separation out of otherness as such is derived from the failure of mutual recognition on the part of two self-consciousnesses who encounter each other and refuse to recognise the other as itself a selfrelation. This applies to oneself as other and, equally, to any opposing self-consciousness: my relation to myself is mediated by what I recognise or refuse to recognize in your relation to yourself; while your self-relation depends on what you recognize of my relation to myself. ${ }^{66}$

In this passage, Rose makes the profoundly intersubjective nature of the Hegelian dialectic clear. This aspect of recognition is represented as the activity of only one self-consciousness, and thus it appears that self-consciousness posits its other, and the action is that of only one self-consciousness. However, "the other is equally independent and self-contained, and there is nothing in it of which it is not itself the origin." ${ }^{67}$ The action that is necessary for recognition is both that of each self-consciousness acting individually; it is of double significance because it is the action of each self-consciousness acting against itself as well as against the other self-consciousness.

One conclusion to draw from this aspect of Hegel's theory of the subject (selfconsciousness "A") and intersubjectivity is that the other (self-consciousness "B") is uniquely different and independent from the subject. That is, $B$ is uniquely different

\footnotetext{
${ }^{65}$ Hegel, Phenomenology of Spirit, §184

${ }^{66}$ Gillian Rose, Mourning Becomes the Law (Cambridge: Cambridge University Press, 1996) 74

${ }^{67}$ Hegel, paragraph 182
} 
and independent from A. And certainly, those scholars who laud the political and ethical dimensions of Hegel's philosophy of intersubjectivity do so because of the "respect for difference" that it is seen to entail. Moreover, I argue that this reading of the dialectic of recognition is equally as plausible as the critique that follows; the outcome of the drama of recognition is contingent upon the circumstances in which it unfolds.

However, a more critical reading of this dialectic questions the nature of difference that is cognisable within a recognition paradigm. Recall that the 'other' is simultaneously posited by the self as one extreme aspect of itself, while it is also an independently existing self-consciousness in its own right. How can the particularity, or the difference of the other be said to be kept intact when each self-consciousness requires and relies upon another self-consciousness that necessarily moves towards it own becoming and its other in an identical fashion? What is the nature of difference when what is required by self-consciousness is the recognition of an other that is already designated as a reflection of itself? The other that is required for mutual recognition is one which posits its own other, "comes out itself", and is then absorbed and superceded by itself and its other in an act of mutual recognition and reconciliation (aufhebung). The other that is required by self-consciousness is both a reflection of self-consciousness and also an independently existing other selfconsciousness- but identical, in many respects, to self-consciousness nonetheless.

Jean-Luc Nancy states this problematic in the following way:

[I]dentity, while pulling itself together, assumes and resorbs within itself the differences that constitute it: both its difference from the other, whom it posits as such, and its difference from itself, simultaneously implied and abolished in the movement of "grasping itself." In this way, finally, identity makes difference: it presents itself as preeminently different from all other identity and from all nonidentity; relating itself to itself, it relegates the other to a self (or to an absence of self) that is different. Being the very movement proper to self-consciousness, identity- or the Self that identifies itself- therefore makes difference itself, difference proper: and this property designates or denotes itself as "man."

\footnotetext{
${ }^{68}$ Nancy, "Identity and Trembling" in The Birth to Presence (Stanford: Stanford University Press, 1993) 
Identities of the self and the other- as difference- come to exist as properties in and of themselves. The difference that is posited by the Self is one that is proper to the Self or subject. This difference becomes property in that it designates the human as human, or the subject as human; ${ }^{69}$ this is property in the sense of being a characteristic proper to the subject, and also something that is knowable, quantifiable, tangible, capable of being possessed.

The proper(tied) nature of identity and difference fits within an ontological "economy of the same" ${ }^{70}$ in which difference is not really difference at all, but a presupposed, assumed counterpart to the self-same subject. If, as Nancy postulates, "the life of spirit does not tremble before its own differentiation, not even in death, for there too it maintains itself," the question that remains is "where can a different identity come from? From where can $B$ come to $A ?^{71}$

Hegel maintains that while self-consciousness may be represented as the journey and transformation of one self-consciousness, the other is originarily independent and self-contained. ${ }^{72}$ Nancy responds to this insistent assertion of the independent "origin" of the other self-consciousness by stating that the "the path of self-consciousness can easily lead through desire and recognition of the other, but it is traced beforehand as the circular process of the Self of this consciousness." 73

Nancy's critique challenges the notion that there is any space within the Hegelian dialectic of recognition for the existence of alterity. The difference that is recognized is only ever that which is proper to what has already been established (or represented) as 'man' (or 'humanity'). Placing this critique in the context of the

\footnotetext{
${ }^{69}$ Nancy, "Identity and Trembling" at 10

${ }^{70}$ Derrida, "Violence and Metaphysics: An Essay on the Thought of Emmanuel Levinas" in Writing and Difference (London: Routledge, 1978) p.117

${ }^{71}$ Jean-Luc Nancy, "Identity and Trembling" in The Birth to Presence (Stanford: Stanford University Press, 1993) 9 at 12

${ }^{72}$ Hegel, Phenomenology, para 182

${ }^{73}$ Nancy, "Identity and Trembling", p.11 Derrida also critiques the absolute nature of the economy of difference and sameness as it is manifest in the master-slave dialectic. He argues that "there is no expenditure of life (or thought) that falls outside of Hegel's totalizing discourse of knowledge". See Jaques Derrida, "From Restricted to General Economy: A Hegelianism Without Reserve" in Writing and Difference (London: Routledge, 2001) 317
} 
recognition of Aboriginal difference, I want to suggest that the difference that is recognized is that which is proper to what has already been established as the boundaries of the liberal democratic capitalist state. Thus the "frozen rights approach", to take one example, can be understood as a positing of Aboriginal rights and practices in a time and space that is separate and distinct from the contemporary, post-colonial order in order to avoid any disruptions of the 'present'. The recognition and acceptance of differences between communities (within the boundaries of one nation state) in political organization, economic ideologies and practices, land and resource use, would bend the overarching structure of the nation state out of shape and radically alter its boundaries. This is desirable and necessary in the context of decolonization- and while I do want to conclude that this is impossible within a dialectic of recognition, it has not been realized in the colonial settler context that denies the recognition of difference beyond the bounds of cultural difference.

There is ample evidence in the caselaw to support this view. In the Canadian context, the recognition of the proper Aboriginality is accomplished through the language of cultural distinctiveness, with its criteria of primordial, authentic essence that is consistently used by the courts to narrow or limit the recognition of an Aboriginal right. ${ }^{74}$ Where the Courts do recognize an activity as an Aboriginal right that is commercial in nature, they take steps to circumscribe it in the interests of the "broader social and political community" in which Aboriginal peoples live. Aboriginal rights are being limited "where the objectives of those limitations are of sufficient

\footnotetext{
${ }^{74}$ By the concept of 'limitation' I refer here to the cultural distinctiveness test established in R. v. Van der Peet, as opposed to the doctrine of what constitutes a justifiable limitation on a right that has been found to exist, as set out in $R v$. Sparrow. The "frozen rights" approach contradicts an important aspect of the politics of recognition outlined by Charles Taylor. By defining Aboriginal cultural practices by reference to the pre-contact era, the Court denies the dimension of authenticity that is integral to the assertion and recognition of one's identity. "Authenticity" connotes the real or genuine identity of someone; "[b]eing true to myself means being true to my own originality, which is something only I can articulate and discover." Thus, to deny Aboriginal individuals and communities recognition of their identities as they exist in the present moment is to deny them full recognition. "The Politics of Recognition", at 31
} 
importance to the broader [non-Aboriginal] community as a whole." ${ }^{\prime 75}$ This aspect of Aboriginal rights doctrine, perhaps more clearly than any other, illustrates the violence that is inherent in the process of recognition as it is currently configured within a politics of difference.

The way in which the Court has developed the doctrines of limitation and justification re-inscribes the originary violence of the colonial assertion of sovereignty and proceeds to discipline and regulate Aboriginal communities in a way that is proper to and consistent with Canada's status as a post-colonial settler society. The test for a justifiable limitation of an Aboriginal right was first established in Sparrow. In determining whether a right has been infringed, the Court makes three inquiries: whether the limitation on the right is reasonable; whether the regulation at issue imposes undue hardship; and whether the regulation denies holders of the right their preferred means of exercising the right. ${ }^{76}$ After determining whether there has been an infringement according to these three criteria, the Court then inquires as to whether the infringement can be justified. The test for justification of the infringement of Aboriginal rights mirrors the structure of the Oakes ${ }^{77}$ test under section 1 of the Charter.

Although the Aboriginal rights recognized by section 35(1) are, as was noted in Van der Peet, fundamentally different from the rights in the Charter, the same basic principle- that the purposes underlying the rights must inform not only the definition of the rights but also the identification of those limits on the rights which are justifiable- applies equally to the justification analysis under s.35(1). ${ }^{78}$

\footnotetext{
${ }^{75}$ R. v. Gladstone [1996] 2 SCR 723, para 73

${ }^{76}$ R. v. Gladstone [1996] 2 S.C.R. para 39

77 Section 1of the Charter of Rights and Freedoms, which is in part 1 of the Constitution Act, 1982, provides for the reasonable limitation of Charter rights that can be demonstrably justified in a free and democratic society (Hogg, 2000, 720). The four criterion to be "satisfied by a law that qualifies as a reasonable limit that can be demonstrably justified in a free and democratic society" derive from the judgment of the Supreme Court of Canada in R. v. Oakes [1986] 1 S.C.R. 103. They are the following: 1) the law must pursue an objective that is sufficiently important to justify limiting a Charter right; 2) the law must be rationally connected to the objective; 3 ) the law must impair the right no more than is necessary to accomplish the objective; 4 ) the law must not have a disproportionately severe effect on the persons to whom it applies (Hogg, 2000, 735).

${ }^{78}$ R. v. Gladstone, para 71
} 
Aboriginal rights, which are recognized by virtue of Aboriginal peoples' prior occupation of the lands, are fundamentally different from rights under the Charter, to which every Canadian is entitled. In Van der Peet the majority found the reconciliation of the prior occupancy of Aboriginal peoples with Crown sovereignty to be the primary purpose of s.35(1). The fact of prior occupancy, above any other facts, distinguishes 'Aboriginal peoples from all other minority groups in Canadian society and mandates their special legal and constitutional status. ${ }^{79}$ If this is so, why is the doctrine of justification the same in structure as the Oakes test? ${ }^{80}$ The justification test applied to Aboriginal rights takes on a form and content that is very similar to the Oakes test, masking the very important differences between Aboriginal and non-Aboriginal communities, and their respective relationships to the state. Aboriginal rights are hastily folded back into the existing paradigm of rights discourse in order to "stem the tide" that is unleashed with the acknowledgment of their prior presence on the land.

For example, in Gladstone, the issue before the Court was whether the federal government's Pacific Herring Fishery Regulations, SOR/84-324 were "of no force or effect" by operation of s.52 of the Constitution Act because they infringed the appellant's s.35 right to sell herring spawn on kelp. The Court found that there had been a prima facie infringement of the rights of the appellant. Although the Court ultimately concludes there was insufficient evidence to determine whether the objectives of the government's regulations satisfied the requirement that they be compelling and substantial, the Court makes a number of important and interesting statements in the course of delineating the test for justification. The Court notes that "prior to the arrival of Europeans in North America," the Heiltsuk people engaged in the harvesting of herring spawn on kelp "to the extent they themselves desired." This activity was only subject to limitations presented by "difficulties in transportation,

\footnotetext{
${ }^{79}$ R. v. Van der Peet [1996] 2 S.C.R. at para 30, per Lamer, C.J.C.

${ }^{80}$ Whereas the Charter and Rights and Freedoms is in Part 1of the Constitution Act, 1982, section 35(1) is located in Part 2.
} 
preservation and resource availability, as well as those limitations that they thought advisable to impose for the purposes of conservation." ${ }^{81}$ Quoting from Sparrow, the Court notes that the requirement that the government regulations have a valid legislative objective would potentially be satisfied by the curtailing of an Aboriginal right in the interests of "preserving" the section 35(1) right itself. As Dickson C.J. and La Forest J. wrote in Sparrow, "[legislative] objectives purporting to prevent the exercise of s.35(1) rights that would cause harm to the general populace or to Aboriginal peoples themselves," would also be valid. ${ }^{82}$ This approach does nothing to address the colonial practices that have endangered the fishing stocks in the first place. ${ }^{83}$ This history is smoothed over by the promise that the Sovereign will protect the $s .35$ right by prioritizing Aboriginal communities' interests and upholding their fiduciary duty towards Aboriginal peoples.

The Sovereign power determines and regulates the extent to which an Aboriginal right may be exercised. The prospect of reconciliation is set in motion as the profound power imbalance between Aboriginal communities and the nonAboriginal society (to which they stand in opposition when it comes to a "balancing" of rights and interests) is not accounted for in the course of deciding whether a limitation on an Aboriginal right is justifiable. The justification test posits the recognition of Aboriginal rights- and the limitations of those rights in the interests of the broader community as a whole- as equally as important to reconciliation, thereby ignoring the reality that many of these rights have not been recognized or practiced by Aboriginal peoples throughout the history of colonial settlement. And where these rights have been exercised, they have often been limited in the interests of the nonAboriginal majority.

\footnotetext{
${ }^{81}$ R. v. Gladstone, para 53

${ }^{82} R$ v. Gladstone, para 54

83 Joel Bakan, Just Words: Constitutional Rights, Social Wrongs (Toronto: University of Toronto Press, 1997) 58
} 
Where the Aboriginal right engaged involves economic resources, the Court has tended to circumscribe the right more narrowly, and widen the parameters of what constitutes a justifiable limitation on the exercise of that right. In Sparrow, the right claimed was a right to fish for food, a right which has an inherent limit. There is only so much fish that is required to fulfill this need for food of a particular community. Commercial fisheries, however, which respond to the needs of an insatiable market, have no such limit. The economic development of mines and forests is similarly only restrained by a limit point determined by the people in charge of regulating the exploitation of such resources. Where the Aboriginal right being claimed confronts the economic development of the province or involves capitalist enterprises such as the commercial fishery, the rights and limitation analyses, as well as the justification tests, take on different contours.

Thus in Delgamuukw, the Court finds practically any activity that has as its objective the promotion of economic development in the interior of the province of British Columbia can legitimately infringe an Aboriginal right to title over that land:

In my opinion, the development of agriculture, forestry, mining, and hydroelectric power, the general economic development of the interior of British Columbia, protection of the environment or endangered species, the building of infrastructure and the settlement of foreign populations to support those aims are the kinds of objectives that are consistent with this purpose, and in principle, can justify the infringement of Aboriginal title. ${ }^{84}$

It is telling that practically any activity that promotes the interests of the foreign settler population can "in principle" justify the infringement of Aboriginal title. In Van der Peet, the claimant characterized her claim as the right "to sufficient fish to provide for a moderate livelihood." 85 The Court re-characterized her claim, as noted above, as the right to exchange fish for money or other goods. The majority concludes that although members of the Sto:lo society did engage in the exchange of fish, it was not

\footnotetext{
${ }^{84}$ Delgamuukw v. British Columbia, para 165

${ }^{85}$ R. v. Van der Peet, para 79
} 
a "central, significant or defining feature of Sto:lo society." ${ }^{86}$ The anthropological evidence described throughout the judgment reveals how the exchange of fish was a part of the regular activities of the Sto:lo society. The Court finds that as there was no "regularized trading system" prior to the arrival of the Hudson's Bay Company, at least in the sense of a commercial, capitalist sense, the exchange of fish was not sufficiently widespread so as to constitute a "defining feature" of that society. Trading fish with the Hudson's Bay Company does not fulfill the requirements for the rights test because the activity must have been a defining feature of the Aboriginal society prior to contact with Europeans.

While fishing for food is seen to be a "defining" aspect of Sto:lo society, (as one would imagine is the case with any coastal community), "incidental" daily practices, such as trading fish for money in order to earn a "moderate livelihood" do not fall within the parameters of Aboriginal rights. What is being reconciled with the assertion of Crown sovereignty are activities and practices which, from the point of view of the settler society, were defining features of that community. Anything else that was and is considered "incidental" to such defining characteristics fall outside of the rights "box." 87

This type of reasoning was recently repeated in Mitchell v. M.N.R. [2001] 1 S.C.R. 911 (on appeal from the Federal Court), where the Court disagreed with the trial judge and Court of Appeal who found that the Mohawk of Akwesasne engaged in trade north of the St. Lawrence River (and what is now the U.S.-Canada border) prior to contact with Europeans. The Court went on to conclude that even if they

\footnotetext{
${ }^{86}$ R. v. Van der Peet, para 91

${ }^{87}$ One may speculate on what would be considered a "defining" characteristic of the settler population for the purposes of rights adjudication, from the perspective of a person who comes from a radically different society. Is the right to equality for instance, a "defining" characteristic of our day to day social, cultural and political practices, or is it merely incidental to the dominant and definitive activities of earning a livelihood, and exchanging money for goods? Is the right to freedom of expression a defining characteristic of our society, or is it merely incidental to the distinctive institution of property ownership and freedom to contract?
} 
acknowledged the existence of such trade, it was not an "integral" aspect or "defining" character of this Mohawk community. ${ }^{88}$ The Court finds the following:

[Trading goods across the St. Lawrence River] was not vital to the Mohawk's collective identity. It was not something that "truly made the society what it was" (Van der Peet, at para 55 (emphasis in original)). Participation in northerly trade was therefore not a practice integral to the distinctive culture of the Mohawk people. ${ }^{89}$

It is difficult to imagine a situation in which trade for commercial purposes could ever be characterized as a defining cultural feature of any society, or to turn this proposition around, where commercial activities could ever be separated from the defining cultural features of any society.

It is apparent that the recognition of Aboriginal rights is circumscribed by an economy of difference in which that which is recognized is always already proper to existing political, legal and economic structures. "Culture" and cultural difference is the particular modality through which any 'difference' that would transform the existing whole that is the nation is contained. The desires of Aboriginal rights claimants are continually negated in this process. Does the concept of a sui generis legal take us beyond these limits?

\section{B. The persistence of essence and authenticity: sui generis transformation or the preservation of difference?}

As discussed above, Borrows argues for the co-mingling of different legal orders that would result in a sui generis law. In the Anishinabe ${ }^{90}$ legal narratives that Borrows presents animals and non-human life, along with other generations (both 'past' and 'future') are represented. It is not just that animals and plant life are

\footnotetext{
${ }^{88}$ M.N.R. v. Mitchell [2001] 1 S.C.R. 911

${ }^{89}$ M.N.R. v. Mitchell, para 60

${ }^{90}$ Anishinabek is a term of self-description for Algonquian speakers around the Great Lakes. John Borrows' reserve is the Chippewas of the Nawash on the Bruce Peninsula in Ontario, Canada. His recounting of the Anishinabek story is based on the story as told to him by his relative John Nadjiwon of Neyaashiinigming and reinforced by the writings of Basil Johnston, also of Neyaashiinigming (Borrows, 16).
} 
considered as important resources or commodities and are for those reasons, placed at the heart of the legal consideration of issues of resource use. Rather, the animalhuman distinction which undergirds most if not all of an androcentric western philosophical tradition is very much reconfigured within Anishinabek 'ontology' or philosophy of being. This reflects a disjuncture that cannot be contained within the word 'difference'.

Borrows illustrates how Aboriginal laws could be usefully deployed in the context of environment and planning law. Borrows draws upon Aboriginal legal knowledge and relays it in a form cognisable to those versed in western common law concepts. He relays a combination of Anishinabek stories, putting them into a caselaw format, to illustrate both the 'stability and flexibility' of Anishinabek law and also to show that it is a 'combination of First Nations stories that create law.' (16) In these stories, it becomes clear that Anishinabek law reflects epistemological and ontological foundations whose difference from a western history of philosophy is immense.

Several aspects of Nanabush $v$. Deer, Wolf et al ${ }^{91}$, for instance, reflect a radical departure from western legal and philosophical precepts. To begin with, the case takes place in the "distant mists of time". The temporality of the stories being relayed are neither linear nor cyclical; certainly, they are a part of an oral history tradition that is passed down through generations, but there is no exact point of departure for this particular case as it is reinterpreted with each telling in order so that it may be responsive to ever-evolving contemporary circumstances. Second, the legal principles that we might derive from the case include the principle of interrelation between animals and human life. However, this is not only a recognition of interdependency, these principles derive from stories in which animals have agency; their actions (like the passive observations of the deer during the battle of the birds against the Anishinabek nation) are interpreted as significant indications of what the

\footnotetext{
${ }^{91}$ (Time Immemorial), 0002 Ojibway Cases $\left(1^{\text {st }}\right) 3$ (Anishinabe Supreme Court)
} 
outcome ought to be. The value system which shapes the legal determination or outcome includes the needs of animals - as placed within a larger economy of interdependency between non-animal, animal, and human life. ${ }^{92}$

Although Borrows does not use the word "capitalism", he notes that North American democratic systems are under pressure to maintain current levels of material consumption and the requisite economic activity; this pressure is exacerbated by "a hegemonic alignment of interests, institutions, and ideas that enable some to gain enormous political and economic power by over-exploiting the environment." ${ }^{93}$ I think that Aboriginal legal knowledge is meant to entail approaches to resource use and land use planning that are different from current environmental concerns about the exploitation of the environment by rampant capitalist forces.

Borrows argues for a reconfiguring of the relationship between humans, animals and their environment, one that accounts for the "literal connection and interaction between those things in the environment that act to use their surroundings, and those that are acted upon." In arguing that "[a] compact between humans and their surroundings must be considered when humans make governmental decisions about themselves and their neighbours" 94 Borrows advocates for a democracy in which the interests of non-human elements are represented within the polity.

However, the liberal democratic capitalist system which is 'straining to sustain the current level of economic activity and material consumption' is premised on a view of animal and 'plant' life, of forests, rivers, and entire eco-systems as commodity objects to be exploited for the benefit of humans. The shift to a different social contract or "treaty" 95 between human, animals and the environment would undermine the very foundation of laws (resource law, property law, land use planning law, etc..) that are implicated in and buttress a liberal capitalist legal order.

\footnotetext{
92 Borrows notes that "each culture has somewhat different perceptions of space, time, historical truth, and causality." Recovering Canada, 90

${ }^{93}$ Borrows, 31

94 Borrows, 47

95 Borrows, 19
} 
My question is not whether this type of change is desirable (indeed it is), but whether this transformation of existing modes of land and resource use and the laws that structure such uses can be accomplished within a paradigm of recognition. The 'recognition' and realization in practice of Aboriginal concepts such as treaties and covenants between humans and the environment- and the different configuration of the distinction between human, animal and environment would not leave the overall legal and political structure intact. Borrows is not arguing for the exceptional allowance of (some) different modes of land and resource use. The forging of a "truly North American law"96 in the context of environmental law would require the fusing or melding of different conceptions of the relationship between humans, animals and the environment, as well as a deep re-evaluation of the conceptualisation of animals and the environment as mere commodity objects available for human use. The knowledges and ways of being that Borrows is seeking to assert as in need of legal and constitutional protection cannot be described, in shorthand, as cultural difference.

The transformation of environmental law and resource use would result in a type of law that would not be recognizably Aboriginal or Anglo-American, but something quite unique unto itself, that is, sui generis. Borrows' vision of the transformation of Aboriginal and Anglo-American legal orders into a new body of law, while the difference of its component parts is maintained could be said to reflect the accomplishment of a dialectic of recognition. Hegel's concept of the dialectical resolution of a contradiction or opposition, encapsulated by the term Aufhebung, reflects a moment in which difference is overcome in [a] unity but is also preserved. In the words of Hegel, "it is a "difference which, in itself, is no difference." ${ }^{97}$ However, even if we accept that the concept of a sui generis body of law were to resolve the apparent oppositions between Aboriginal and non-Aboriginal legal knowledges, while

\footnotetext{
96 Borrows, 51

${ }^{97}$ Hegel, Phenomenology, para 167
} 
at the same time, preserving their differences, the problem of essence would rear its head again.

This is not to deny that there are differences between Aboriginal and nonAboriginal communities; my aim is to question how this difference is characterized within a paradigm of rights, and what aspects of these differences are relevant to the formation of political community and its relationship to law. Borrows advocates for the conceptualisation of Aboriginal rights on the basis of practices that are necessary for the cultural and physical survival of the community. The notion of "Aboriginality" persists in his conception of rights, along with the desire to "preserve difference".

Why does the desire to preserve (cultural) difference persist? How can we advocate, as Borrows does, for a notion of community that is not defined through a notion of biologically based or socially constructed racial difference, nor through simple territorial boundaries, kinship, or notions of tradition and culture as static and unchanging ${ }^{98}$, and at the same time, desire the preservation of a 'difference' that can only be ('different') if it maintains an essential difference in relation to other discrete communities? I think it is useful to separate the desire for the continual existence and realization of "community" as a place where particular epistemological and ontological frames for how individuals relate to each other and their environment can flourish- from the desire to preserve this set of differences in the name of (the much more limited idea of) "cultural" difference. ${ }^{99}$ I render this critique reluctantly, because Borrows writes in the context of a very real backlash and resistance to the notion of Aboriginal rights. ${ }^{100} \mathrm{I}$ am sympathetic to the view that in the face of a history of attempted genocide and myriad forms of repression, naming resistance to colonial practices as 'Aboriginal' or 'indigenous' is important and perhaps unavoidable. However, I argue that at the same time, we need to name this politics of resistance 
and post-coloniality differently, in such as way as to heed Fanon's call of avoiding the pitfalls of (ethnic, racial) national consciousness.

\section{Rehabilitating the rule of law: casting ourselves into a space of 'unfreedom'}

Borrows' discussion of the rule of law is "motivated by the very conservative notion that the consistent application of the rule of law and the inclusion of Aboriginal perspectives can provide an important bulwark against arbitrariness and oppression..101 From the perspective of Aboriginal communities, the arbitrary assertion of Crown sovereignty has caused (and continues to cause) severe disruptions, chaos and even near-anarchy. In reaching back to Aristotle for a definition of "rightly constituted laws" as the "final sovereign", as complete, nonarbitrary and unbiased, Borrows posits the rule of law as a transcendent ideal that can be realized 'now' if a consensual, unbiased, inclusive, and non-arbitrary approach to the legitimacy of Crown sovereignty is undertaken. However, in positing the use of law and the legal justifications for the appropriation of Aboriginal land, creation of reserves, and myriad other forms of political and economic subjugation of Aboriginal peoples as simply 'wrong' or in breach of the real or true ideal of the rule of law, I think Borrows lets 'the law off the hook' too easily.

At the time of settlement, the assertion of Crown sovereignty was accomplished in the name of 'the rule of law' that Borrows wants to rely upon as the basis for a just legal and political order. As Fitzpatrick writes:

[E]very tale of law's bringing order to disordered times and places, along with the triumph of such things as modernity or capitalist social relations, can be matched by others where it created uncertainty and inflicted massive disorder in the same cause. ${ }^{102}$

The 'rule of law' was used as a basis for the establishment of colonial sovereignty, bringing such things as order, stability and peace to colonial settler society. At the

\footnotetext{
101 Borrows, 115

102 Peter Fitzpatrick, Modernism and the Grounds of Law (Cambridge: Cambridge University Press, 2001) 71
} 
same time, it caused massive disruption for the colonized. The rule of law is intimately connected to the very same colonial 'sovereignty' that Borrows would like to call into question. The rule of law, in fact, could be seen to depend on sovereignty itself. The rule of law depends on the existence of a sovereign power. Sovereignty is defined through its exclusive monopoly over power. Borrows argues that because there was and is no legitimate basis for the assertion of colonial sovereignty, there was an arbitrary abuse of power which violated the rule of law. But there could be no 'rule of law' without the assertion of a putatively "absolute" or totalising sovereignty.

Law demands and requires a foundation- a founding act- which is inherently violent. While law may alter this 'originary moment' in order to be responsive to ever changing circumstances and conditions, it will always do so in order to preserve its own foundations ${ }^{103}$ and its power. This foundation in the Canadian context is colonization and in legal terms, (colonial) Crown sovereignty. Borrows argues that a more peaceful and productive future demands a disruption of existing socio-political relations, and the positing of a just foundation. It is not this fact that I take issue with, but rather, the impossibility of creating a just foundation through the deployment of the rule of law which it tied to the colonial sovereignty that is supposed to be excised.

Concepts such as "rule of law", and "democracy" as they have developed within a liberal capitalist order have been predicated on the rights and freedoms of some at the expense of others- and this colonial nature of legal concepts has not been limited to Aboriginal communities. Borrows' advocacy of the rule of law as a basis upon which to call for the just treatment of Aboriginal peoples can only be done if it is abstracted from the context out of which it grew. Notions of freedom that grew out of the Ancient philosophical tradition that Borrows invokes are not "philosophical absolutes or tangible entities" but take shape in opposition to whatever exists in "unfreedom":

\footnotetext{
${ }^{103}$ See Peter Fitzpatrick, 70-81
} 
Liberal freedom, fitted to an economic order in which property and personhood for some entails poverty and deracination for others, is conveyed by rights against arbitrary state power on one side and against anarchic civil society or property theft on the other. As freedom from encroachment by others and from collective institutions, it entails an atomistic ontology, a metaphysics of separation, an ethos of defensiveness, and an abstract equality. Rendering either the ancient or liberal formations of freedom as "concepts"... not only prevents appreciation of their local and historical character but preempts perception of what is denied and suppressed by them, of what kinds of domination are enacted by particular practices of freedom. ${ }^{104}$

There is no tradition to which we can go back, make right, or invoke in a movement towards decolonisation.

\section{Conclusion}

I have attempted, in this review essay, to raise some doubts about the political efficacy of a theory of recognition generally, and particularly, as it is configured within a politics of difference. I have argued that within the Hegelian paradigm of recognition, the only difference that is recognized is that which is proper to the totality or entity that is already inscribed as the subject, the community, or the nation. On the basis of this argument, I argued that Borrows' notion of sui generis body of law may accomplish the fusing or melding of a plurality of legal orders, but for this very reason, cannot be accomplished through a dialectic of recognition as it is currently configured within a liberal paradigm of identity/difference. And if it is desirable because it successfully "fuses [different] horizons," ${ }^{105}$ the preservation of a difference based on cultural, ethnic or racialized identities remains problematic because it raises the spectre of essence and essentialized identities as the basis for inclusion in community. Finally, I have raised a different set of concerns about the viability of redeploying foundational concepts such as the 'rule of law' in an effort to decolonize the Canadian state.

\footnotetext{
${ }^{104}$ Wendy Brown, States of Injury, 6

105 See Andrew Schaap, "Reconciliation Through Struggle for Recognition?" in Social and Legal Studies 13 (4) (2004) 523 at 529
} 
While I have raised several questions, Borrows' vision of a sui generis legal and political order is an attractive proposal for a way to think about the formation of a decolonised political community. Placed outside of the paradigm of recognition as it has been translated into the language of cultural difference, the idea of acknowledging and realizing (through the material reorganization of control and access to resources) a plurality of sovereignties, legal orders, modes of land and resource use, and types of relationships between humans, animals and the environment could potentially shift social relations in a significant and meaningful way.

The concept of a sui generis legal order, that is the result of the encounter, mutual recognition, and transformation of different legal knowledge(s) holds the potential for the ongoing movement or relation- between individuals that constitute communities and between 'communities' as entities. The question is not how to recognize identity/difference, but how to recognize movement, ${ }^{106}$ the movement and continual change that in fact constitute the ongoing formation of the subject and its relation to its environs. Sui generis legal knowledge and practice does not have to be about achieving a fixed or comprehensible end point- a new body of law that represents Aboriginal and non-Aboriginal legal orders- but exists in the desire for an open ended relation between bodies of knowledge and relations between selves.

\footnotetext{
${ }^{106}$ Scott Lash and Mike Featherstone, "Introduction", Recognition \& Difference: Politics, Identity, Multiculture (London: SAGE, 2002) 10
} 